\title{
Public Participation in Rural Development Planning in Semarang Regency
}

\author{
Tijan $^{1}$, Erisandi Arditama ${ }^{2}$, Wenny Eka Septina ${ }^{3}$ \\ $\left\{\right.$ tijan@mail.unnes.ac.id ${ }^{1}$, erisandi@mail.unnes.ac.id ${ }^{2}$, wennyeka@mail.unnes.ac.id $\left.{ }^{3}\right\}$ \\ Universitas Negeri Semarang, Indonesia ${ }^{1,2,3}$
}

\begin{abstract}
Law No. 6 of 2014 concerning Rural provides an opportunity themselves to carry out participatory rural development planning processes by involving the community as much as possible. However, the reality on the ground shows that not all regions have local regulations on rural development planning and the role of sectoral institutions in this process is still dominant. This research seeks to describe how public participation in rural development planning, by taking a case study in Semarang Regency. This research is product oriented and is designed using the CIPP (Context, Input, Process, and Product) model. The results show that in Semarang Regency formally, the procedure for preparing rural development plans still refers to higher regulations, namely regulations issued by the Ministry of Villages. On the other hand, symptoms of the emergence of awareness of the importance of public space and dialogue efforts in utilizing existing public spaces for all components of society to build their villages are clearly visible. Development program planning is very synchronous with the implementation of regional development programs, realized by the nature of partnerships and togetherness among community members. In fact, the role of actors who are less able to encourage change, such as the role of village clerics who no longer determine the determination of development programs. Therefore, forms of community participation, both direct and indirect, should be applied at all levels and at all stages of the program determination process.
\end{abstract}

Keywords: Participatory Planning, Rural Development, Public Space.

\section{Introduction}

Law No. 6 of 2014 concerning Rural provides autonomy to rural communities. The consequence of the autonomy is to determine that the Rural Government in compiling Rural Development planning in accordance with its authority, refers to the Regency / City development planning (Article 79). However, in Indonesia (especially Java), up until now not all of them have a Regional Regulation reference on Village Development Planning that is needed by stakeholders in the village, sub-district or district [1]. In fact, the Regional Regulation on Development Plans is a very important regional policy in order to regulate and manage regional household affairs [2]. Regional Regulation is very important and strategic because it is a reference and guideline for regional government actions in organizing public services, development to grow the people's economy (development), and providing protection to the community (protective) [3].

In compiling village development planning, the village government is obliged to hold village development planning meetings. This model is known as participatory development planning. In making development planning it must involve the community because the community is both 
the actor and the party directly affected by the development activities as outlined in the development plan. Conceptually, at this time the Ministry of Villages, Disadvantaged Regions and Transmigration of the Republic of Indonesia, has introduced a Village Development Planning Guide [4] which is a continuation of the Village Development Planning, Implementation and Control (P5D) model. The P5D mechanism and village development planning within the framework of building community planning together try to involve the community as much as possible. Planning from the community (bottom up planning) is integrated with the planning of sectoral agencies / agencies (top down planning). However, in its implementation, village development planning has not been participatory such as the concepts and policies developed. Because, planning from above, which was compiled by SKPD, more dominated the results of planning.

This is consistent with the research conducted by the author in 2005 in Demak regarding Regional Development Planning. The results showed that the development planning process was still dominated by the District Government using a bottom-up approach that was engineered and then followed closely by the government. In line with the things that have been stated above, the existence of a model for developing village development planning that involves all elements of society is an urgent need. This is based on public awareness about the coming of the reform era which demands the implementation of democratic governance in order to create sustainable community welfare [5].

\section{Research Methods}

This research is product oriented and is designed using the CIPP (Context, Input, Process, and Product) model (Stufflebeam in Madaus 1983: 117). This research conducts context analysis and input which will be used to clarify the model of village development planning in Java. Some of the things that are needed include the form of strategies developed, the implementers and assistants needed, the stages that must be passed, and the simple flow framework regarding data alignment and community idea extraction. The excavation was carried out by the in-depth interview method with several informants who were considered to represent the community being studied (Rithcie and Spencer, 2002).

\section{Results and Discussion}

\subsection{Understanding Participatory Development Planning at the Local Level}

In every planning activity plays a very important role. Turner and Hulme (1977: 132) explain that planning is a conscious and continuous and organized effort to choose the best alternatives available in order to achieve specific goals. Furthermore, Martin et al (2014) describe participation in development planning through unconventional forums. Some examples are proposed, for example through online forums.

Following on from Friedman (1987), policy planning discourse in Third World countries was further elaborated by Grindle (2017). In his idea, Grindle mentioned that in practice, policy planning is not merely an administrative problem, but rather a political process in it. Another important aspect in policy planning is regarding the text and the context of development that will be carried out (Seftyono, 2012). 
On the other hand, the issue that is no less important in development planning is community participation. Broadly speaking, community participation is a community movement to be involved in the decisions making process, in implementing activities actively, enjoying the results of these activities, and participating in evaluating them (Uphoff, 1992; Paul, 1987; Owusu, 2016).

While participatory development is based on partnerships formed through dialogue between various actors to produce a jointly set agenda, where people's inspiration and knowledge are taken into account and valued. This means that negotiations take precedence over unilateral decisions by the government, and also the community is treated as an actor rather than as a user (OECD, 1994). Thus, participatory village development planning is a model of development planning that the government delegates to the village community to actively involve themselves in identifying problems, problem makers, finding alternative solutions to problems, preparing a solution agenda, actively involved in the conversion process, participating in monitoring implementation, and participate actively in evaluating. In practice the community is represented by the power of the community consisting of political groups, interest groups and pressure groups. At this level, public or public participation can take the form of innovations and public involvement in dialogue to be inevitable (Papadopoulos and Warin, 2007; Burgess, 2014).

\subsection{Participatory Development at the Village Level}

Village development planning is arranged in a long term covering the Medium-Term Village Development Plan (RPJMDes) for a period of 6 (six) years and the Annual Village Development Plan or what is called the Village Government Work Plan (RKP DESA). The Village RKP is a translation of the Village RPJM for a period of 1 (one) year. Village Medium Term Development Plans and Village Government Work Plans established by Village Regulations.

Making village development planning requires several stages of activities: 1) understanding of the Village. This stage is carried out by analyzing the state of the village so that a village profile / portrait is seen which shows the physical, geographical, socio-economic, socio-cultural, environmental conditions, village problems, village potentials, and their opportunities and challenges; 2) formulation of policies, namely the formulation of policies to be carried out which includes determining the vision and mission, goals, direction of development, general strategy, and village development priorities; 3) formulation and determination of programs or action plans as guidelines for the implementation of village development, and 4) monitoring and evaluation, namely correction / rectification if there are deviations and feedback for further planning.

\subsection{The Dynamics of Development Planning at the Village Level: A Case in Semarang Regency}

General procedures or steps in the preparation of village development program plans in Semarang Regency, referring to the Village Development Planning Guidelines issued by the Ministry of Villages, Disadvantaged Regions Development, and Transmigration of the Republic of Indonesia, namely Book 6: Village Development Planning in 2015. Village Development Planning covers two models are: The Village Medium Term Development Plan (RPJMDes) and the Village Annual Development Plan or the so-called Village Government Work Plan (RKP DESA). However, the reality of the field proves that at a certain regional level in the village, for example at the RT and RW levels and social groups in the area, the procedures and steps are determined by themselves. In developed country societies like America this is common, as 
revealed by Teune (1995) with the term "home rule movement", which is an autonomous legal environment in determining what is best for them.

The steps in village development planning, based on the concepts offered by the Ministry of Villages, Development of Disadvantaged Regions, and Transmigration of the Republic of Indonesia, issued in 2015 covering the Compilation of the Village RPJM, are carried out with activities that include: $a$. the formation of the village medium term development plan; $b$. aligning policy direction for district / city development planning; c. assessment of village conditions; $d$. preparation of village development plans through village deliberations; e. compilation of village mid-term development plans; f. compilation of village development plans through village development planning meetings; and g. the stipulation of the village medium term development plan.

The steps in village development planning as stated above, as a process can be interpreted through two dimensions. First, the formal dimension. These steps are stages that must be passed in planning or development planning, and usually have been determined from above, or agreed upon by community members. Second, the substantial dimension. In these steps contained a decision-making mechanism, which implies a struggle for interests and the implementation of institutional functions or even actors (stakeholders) who play in certain structures in society.

First dimension describes the stages of village development planning in accordance with applicable regulations and existing local community agreements. From this point of view, the existing planning steps are usually rigid and instructive. This means that the existing steps have been formatted so that they are ready to be implemented, and no longer provide the possibility of changes or adjustments to the conditions on the ground. This was reinforced by the government strong control system.

This formal dimension in social theory corresponds to structural theory. In this theory human activities are very much determined by structure such that there is no room for conscious selection. In other word the possibilities that exist mostly contain a single choice (Tom R. Burns, 1987). Therefore, in making decisions about the public needs of the community that it has always been an object or a very small chance to participate in voicing their interests. Structurally, the common people are in the lowest position.

The second dimension, namely the substantial dimension shows a decision-making mechanism, in which there is implied a struggle for interests and the implementation of institutional functions or even actors (stakeholders) who play in certain structures in society. Stakeholders in this case can be interpreted in two senses. First, stakeholders are parties who have an "interest and influence" on a village development activity, which can be inside or outside the organization (work unit) concerned. For example, they are community leaders or actors who are in the management of LKMD, BPD, and village entrepreneurs. They can also be administrators of environmental organizations (such as RT, RW, and Dusun), leaders of village social organizations (such as LKMD, Cooperatives, mosque takmir, etc.), students, NGO activists (NGOs), and the press. Second, stakeholders as parties who benefit and / or feel the effects of a village development activity. They are mostly villagers. So, stakeholders in the broadest sense are all villagers who have an interest in the planning and development process.

Those with the above interests, both in the first and second terms above, jointly participate actively in the village development planning process. The villagers began to feel the existence of public space (the public sphere) that they could use to fight for their fate, which during the New Order they did not get. This public space, in fact, according to Prof. Soetandyo Wignjosoebroto, in fact has been owned by villages of the colonial era, namely "the village characterized by what is known as Ter Haar droprepublieken than what was found at the time of independence. This happened when villages were dissolved and co-opted as components of 
a new organizational system called the Republic of Indonesia (Marut, 2000 and Wignjosoebroto, 2000).

What was found at the research location, the symptoms of the emergence of awareness of the importance of public space and dialogic efforts in utilizing the existing public space for all components of society to build their villages are clearly visible. This process calls for discussion or deliberation to decide on all shared interests between citizens, both within the local area (RT, RW and Dusun) as well as within existing social community groups, such as Dasawisma, PKK, LKMD, Foundations, Mosque takmir-takmir, cooperative groups, and so on.

Among the most prominent field findings, especially regarding informal social institutions, is the nature of partnerships and togetherness in development, is the process of determining (planning) development programs that are very synchronous with the implementation of regional development programs. The result is the success of residents in self-help building local roads with a paving system. It is very clear how the people work hand in hand and work together to build their territory in accordance with their understanding and ability and agreement.

In addition to the dialogical process developed in utilizing the public space that began to be open to the community since the collapse of the Soeharto regime, the open public space also made the opportunity for the birth of social groups (grassroots organizations) outside the structure in villages in Semarang Regency. Those who become administrators and members usually have considerable access in encouraging the birth of democracy in determining village development programs. The proof is that the members of the local community dared to refuse to support the development program set by the village government through village consultation meetings, if the program was not in line with the community's readiness and needs. These institutions have succeeded in changing the structure of village power, as well as the functions of decision making and development control.

A substantial dimension in the procedures and steps of village development planning as described above, in the context of social science theory is relevant to the Actor-System Dynamic (ASD) theory. According to this theory, human choice is important in determining the social action and structural development of social systems, especially the elites among them. However, according to R. Burns and Phillippe De Ville (1987), the ability of social actors, even the ruling elites and actors gave birth to social structures, cultural formations and patterns of social action that benefit their own interests, is very limited.

At the research location, the symptoms of the introduction of ASD theory began to appear, although it cannot yet be said to exist. Evidence of the waning role of actors or elites who are less able to drive change, such as the role of village clerics who no longer determine the determination of development programs in general, even some local elites (for example, heads of RT / RW and hamlet heads) in the village being sued their existence as representatives of citizens in broader interests (development planning at the village level), in fact there are RT and RW heads who are demoted from their positions, because they clearly highlight their personal interests in their positions. Many social activities or actions are actually initiated by those who previously did not have big powers. Ideas about establishing cooperatives, social educational institutions (which turned out to be in great demand), such as TPQ / TPA, public libraries or reading parks, and so on, were born from elementary school teachers, study groups and village youth.

Social realities that are relevant to social theories as outlined above, will in turn give birth to social changes in rural communities, especially in the development planning process that is in accordance with their real aspirations and needs [6][7][8]. Based on observations and acknowledgments from the field informants, there were at least four benefits that began to be felt by the villagers of the study site from the opening of public space and the dynamics of the 
role / actors of local elites, namely villagers as actors or subjects of development aware of the intentions and objectives of their activities. do it; the occurrence of exploration and potential censorship because of their mutual magnitude and determination to carry out an agreed activity; a growing sense of solidarity, a sense of belonging and a sense of togetherness that will support the continuation of the development process; and the process of mutual learning between development actors.

\section{Conclusion}

Referring to what has been described, the conclusion can be formulated that participatory village development planning in the context of strengthening local autonomy to be built has implications that require three conditions, namely: (1) village development planning must be carried out using democratic procedures (bottom- up); (2) it is absolutely necessary to change the pattern of relations between the government and the people towards a pattern of relationships that is imbued with the principle of equality, respect and care in the process of village development planning; and (3) forms of community participation, both direct and indirect, should be applied at all levels and at all stages of the program determination process.

\subsection{Suggestion}

Based on the results of the study it is recommended that the Semarang Regency Government immediately draw up a Regional Regulation (Perda) on Participatory Development Planning that is able to strengthen autonomy at the local level. This regulation will later become a specific guide according to local problems and potentials in village development planning.

\section{References}

[1] R. E. Purba, "Public Participation in Development Planning: A Case Study of Indonesian Musrenbang.," Int. J. Interdiscip. Soc. Sci., vol. 5, no. 12, 2011.

[2] C. Lay, “Otonomi daerah dan keindonesiaan," J. Ilmu Sos. dan Ilmu Polit., vol. 5, no. 2, pp. 139-162, 2001.

[3] J. R. A. Butler, E. L. Bohensky, W. Suadnya, Y. Yanuartati, T. Handayani, P. Habibi, K. Puspadi, T. D. Skewes, R. M. Wise, and I. Suharto, "Scenario planning to leap-frog the Sustainable Development Goals: An adaptation pathways approach," Clim. Risk Manag., vol. 12, pp. 83-99, 2016.

[4] R. Djohani, "Panduan penyelenggaraan musyawarah perencanaan pembangunan desa," Bandung Asia Found. dan FPPM, 2008.

[5] E. M. Biggs, E. Bruce, B. Boruff, J. M. A. Duncan, J. Horsley, N. Pauli, K. McNeill, A. Neef, F. Van Ogtrop, and J. Curnow, "Sustainable development and the water-energyfood nexus: A perspective on livelihoods," Environ. Sci. Policy, vol. 54, pp. 389-397, 2015.

[6] J. Hagen, Community in the balance: Morality and social change in an Indonesian society. Routledge, 2015.

[7] D. Wrong, Power: Its forms, bases and uses. Routledge, 2017.

[8] D. Ivison, "Pluralising political legitimacy," Postcolonial Stud., vol. 20, no. 1, pp. 118$130,2017$. 
